\title{
ХРИСТИЯНСЬКІ КОНЦЕПТИ В ІСТОРИЧНИХ ДРАМАХ Г. ЛУЖНИЦЬКОГО
}

У статті досліджено історичні драми Г. Лужницького (літературного та театрального критика, драматурга, поета, історика української ичеркви та театру, редактора, публіциста, громадського діяча, який працчював у Львові впродовж 1920-40 рр., потім на еміграції у Празі, Граці, пізніше у США), щчо їх автор писав здебільшого для постав у театрі «Заграва» у 1930-х рр. Драми розглядаються крізь призму християнського світогляду, щзо є основним художнім методом автора - за відсутності конкретних біблійних тем, у драмі є чіткі та впізнавані релігійні християнські сюжетні схеми, також автор піднімає проблеми національної боротьби з точки зору християнської моралі та етики.

Ключові слова: історична драма, християнський концепт, сюжетна схема, літературна критика, театральна критика.

The object of the article are historical dramas of Hryhor Luzhnytskyi (literary and theatrical critic, author, poet, historian of the Ukrainian church and theatre, editor, publicist, that worked in Lviv during 1920-40, then on emigration in Prague, later in the USA), that an author wrote mostly for the theatre "Zagrava» in 1930 th. Dramas are examined through the prism of Christian world view that is the basic method of the author. In default of concrete biblical themes, there are clear and knowable religious Christian charts in drama. The author lifts the problems of national fight from the point of view of Christian moral and ethics. In default of concrete religious theme, there are clear and knowable religious Christian with a plot charts in historical dramas.

Keywords: historical drama, christian concepts, a plot chart, literary criticism, theatrical criticism.

В статье исследованы исторические драмы Г. Лужницкого (литературного и театрального критика, драматурга, поэта, историка украинской цееркви и театра, редактора, публициста, общественного деятеля, который работал во Львове на протяжении 1920-40 г2., потом на эмиграции в Праге, Граце, позже в США), которые автор писал по большей части для театра «Зарево» в 1930-х г2. Драмы рассматриваются сквозь призму христианского мировоззрения, которое является основным художественным методом автора, - при отсутствии библейских тем, в драме существуют четкие и узнаваемые религиозные христианские сюжетные схемы, также автор поднимает проблемы национальной борьбы с точки зрения христианской морали и этики.

Ключевые слова: историческая драма, христианский концеет, сюжетная схема, литературная критика, театральная критика.

Актуальність проблеми. У багатовекторній драматургічній спадщині Г. Лужницького досі знаходимо недосліджені аспекти. Драматичні твори автора становили значну частину репертуару знакового для України театру «Заграва» у 1930-х роках. 3 одного боку, драматургія, зокрема історичні драми, відзеркалювала запити часу, з іншого - формувала ці запити на українську християнську ідентичність. Сьогодні маємо можливість оцінити вагу і значення історичних драм Г. Луж- ницького для історії та розвитку не лише українського театру, а й української християнської ідентичності.

Аналіз останніх досліджень $і$ публікацій, у яких започатковано розв'язання цієї проблеми і на які спирасться авторка. Дослідження літературного спадку Г. Лужницького, зокрема драматургії, починаються у працях Л. Рудницького [10], продовжуються у працях Хороба I. [11]. Про аспекти національної ідеї та релігії у драматургії 
Г. Лужницького читаємо у працях Вівчарик Н. [2] та Дмитрів I. [6]. Історія прапрем'єр драматурга опрацьовувалась дослідниками Волицькою I. [4], Кошелінською М. [8], Лаврентієм Р. [10].

Mema cmammi - здійснити комплексний аналіз історичних драм Г. Лужницького. Виокремити основні аспекти, особливості, унікальність історичної драматургії автора.

\section{Виклад основного матеріалу дослідження.}

Григор Лужницький відомий як літературний i театральний критик, драматург, поет, історик української церкви та театру, редактор, публіцист, громадський діяч, який працював у Львові впродовж 1920-40 рр., потім на еміграції у Празі, Граці, пізніше у США. У історичних і теоретичних працях автора виразно звучить ідея українського націєтворення і особливої ролі Церкви у цьому процесі. Такі позиції виявилися у очевидному конфлікті з радянською ідеологією, у полі якої остаточно опинилася західна частина України по Другій світовій війні. Тому ім'я Григора Лужницького було викреслене з культурної спадщини, а повертатися поступово почало зі здобуттям незалежності України. Сьогодні важливо актуалізувати творчість і наукові праці Г. Лужницького, відновити тяглість із сучасними науковими реаліями. Нині маємо дослідження про Г. Лужницького як модерного поета, театрального критика, творця, разом із режисером В. Блавацьким, такого нового явища, як «монументальний театр» (1930-ті рр.), а також як автора низки релігійних драм.

Натомість об'єктом аналізу цієї статті будуть історичні драми Г. Лужницького, що їх він писав здебільшого для постав у театрі «Заграва» у 1930-х рр. До них належать такі твори, як «Ой, Морозе, Морозенку», «Дума про Нечая», «Лицарі ночі», «Січовий суд», «Іван Мазепа», «Слово о полку Ігоревім», «Мотря». Наскрізною ідеєю усіх історичних драм Г. Лужницького є пошук національного ідеалу, поетизація героїчного минулого. Власне, основною місією українського театру на поч. XX ст. Г. Лужницький як теоретик, практик та критик вважає творення української нації, але через модерні засоби та форми. Важливою є роль Церкви у цьому процесі. Вона, на думку Г. Лужницького, не лише сприяла збереженню української ідентичності, а й також завдяки їй було збережено давні театральні форми, від яких розвивається вже сучасний український театр.

Г. Лужницький відкидає версію про «криваве» впровадження християнства на території Київської Русі, висловлену В. Заїкіним 1928 р. у праці «Християнство на Україні за часів кн. Ярополка I
(969-979)» [7]. Не підтримує Г. Лужницький думку про те, що нова релігія категорично відкидала будь-які прояви язичництва і тому зруйнувала традицію передхристиянського народно-обрядового театру. Натомість, як спростування попередньої версії, дослідник наводить як доказ численні народно-обрядові традиції (гаївки, колядки й інші), що збережені донині саме завдяки Церкві, котра не викорінила їx, а, навпаки, вплела у християнські обряди і традиції. Це свідчить якраз не про радикально-революційні методи Східної Церкви, яка, на відміну, від Західної, більш категоричної, адаптувала багато язичницьких традицій. Театральні форми первісного народно-обрядового театру збереглися саме завдяки цій адаптації Східною Церквою. «Всі ці давні традиції, ритуали, святкові пісні та танці як зародок театральних мистецтв змогли вижити, більш того, завдяки охороні церкви вони продовжили свій вплив на ріст та розвиток українських театральних мистецтв через нові теми, нові вистави». [11; 116] Цю ж версію підтримував також історик української літератури М. Возняк, який вважав, що саме церковні «драматичні» Богослужіння якраз і вберегли український театр від абсолютного занепаду в умовах відсутності державності [3]. Не дивно, отже, що у 1930-х рр. зі сцени новоствореного модерного театру «Заграва» (на західноукраїнських землях) звучатиме актуальна тема формування української нації крізь призму біблійних сюжетів та сюжетів 3 історії України. «Театр „Заграва” засновує свій репертуар на переконанні, що одним із суттєвих чинників естетичного зворушення мусить бути масовість настрою. Тим самим шукає він 3 одного боку сюжетів, які давали б надію чуттєвого відгомону в якнайширшій масі і $з$ другого: такого суспільного оформлення, що якнайбільш сприяло б масовій чуттєвій реакції. Таке оформлення найшов театр у свого роду комбінації кінових і містерійних мотивів» $[9,5]$. Це щонайсвіжіший відгук сучасника драматурга - О. Кульчицького, який писав про атмосферу єднання, що панувала на виставі «Слово о полку Ігоревім» 1937 р. Крім того, влучно підмічає реакцію публіки один із глядачів у газеті «Мета»: «Тоді щезла межа між сценою і салею і спонтанний ентузіазм довго ще після спущення завіси не вгавав» $[5,8]$. Аналіз історично-релігійних драм Г. Лужницького, відгуки на їх постави театром «Заграва» у тодішній пресі дають можливість говорити про певний елемент сакрального, що єднав сцену і глядача. «Єдність сцени й зали грунтувалася на національній ідеї, на причетності до власної історії і державницьких 
змагань предків, на вірі в духовне й політичне відродження України» [4, 257]. Більшість історичних драм Г. Лужницького за ненаявності біблійного сюжету та виразної релігійної ідеї все ж можемо віднести до категорії релігійної драми ${ }^{1}$ завдяки християнським топосам, певним біблійним моделям, що закладені в основу творів.

Месіянські мотиви, модель принесення себе в жертву заради друзів звучать у драмах «Ой, Морозе, Морозенко», «Лицарі ночі», «Іван Мазепа». Крім того, оскільки Г. Лужницький був прихильником філософських поглядів В. Липинського, котрі базувалися на переконанні, що важливі історичні процеси відбуваються завдяки сильним і харизматичним особистостям, драматург фактично творить образи таких сильних вольових героїв, історичні образи, котрі межують із міфом.

Драма «Ой, Морозе, Морозенко...» відштовхується від народної пісні про героя часів Хмельниччини. Перед читачем/глядачем постає вже сформований характер, і в драмі ми бачимо героя в момент остаточного вибору, після якого він розпочинає активні дії, що є вже завершенням драми. Це особливий прийом автора - він використовує форму театру дискусії, виводить головного героя із важливим для нього співрозмовником, щоб остаточно проговорити, ніби словесно зафіксувати i аргументувати свій вибір. Для Морозенка - зустріч із батьком (який $є$ представником української, але спольщеної шляхти) є тим індикатором, який остаточно утверджує героя у його виборі, його самоідентифікації як українця. Друга, емоційно напружена і важлива, сцена драми - це момент смерті Морозенка. Це сцена розв'язки, яка йде після кульмінації, котра відбувається за межами сценічного простору. За подієвою логікою кульмінаційним є момент жертви Морозенка він іде на неминучу загибель — підриває мур, щоб дати шлях побратимам, внаслідок чого отримує смертельні рани. Проте, як і в давньогрецьких драматургів, про цю подію глядач дізнається тільки з уст героїв. Саме тому момент розв'язки, коли на сцену виносять раненого Морозенка і в оточенні друзів він помирає, є так званою «тихою» кульмінацією для глядачів. Саме в цій сцені особливо виразно звучить християнська ідея жертви заради друзів. Морозенко у своїх останніх словах звертається до тих, хто його оточує, з усмішкою й проханням не плакати над ним, адже смерть заради друзів - це найкращий кінець. Якщо впродовж

\footnotetext{
${ }^{1}$ Сьогодні категорія релігійна драма описана у істориків театру О. Г. Брокет та Ф. Г. Гілді, Л. Дмитрової.
}

цілої п’єси Морозенко постійно зупиняє пориви козаків до співу, бо це може виказати їх ворогові, то у фіналі останніми словами, навпаки, $\epsilon$ прохання заспівати йому... і козаки починають відому глядачам пісню:

"Ой, Морозе-Морозенку, ти славний козаче,

За тобою, Морозенку, вся Вкраїна плаче...”.

Тихе звучання пісні підсилює емоційний тон всієї сцени, і саме в цьому моменті вочевидь відбувається кульмінація саме вистави - у емоційній співдії з глядачем. Месіанські мотиви у цій п’єсі, хоч і звучать досить яскраво, все ж подані автором окремими мазками.

Більш виразно тема жертви заради друзів і свого народу, а також їі оправданості з християнської точки зору, звучить у «Лицарях ночі». Історична драма про часи зруйнування Січі, написана 1937 року. Лицарями ночі автор називає козаків, таких собі таємних агентів, котрі вбивають московських воєначальників. Такий метод боротьби 3 набагато сильнішим противником $є$ дуже прозорою асоціацією до діяльності ОУН у 20-30$\mathrm{x}$ pp. XX ст. Г. Лужницький у цій драмі піднімає важливе питання оправданості чи засудження методів партизанської боротьби з точки зору християнської моралі. У словесній дискусії, яка розгортається у драмі, звучить думка, що мовчати на злочини проти людської гідності $€$ ще гіршим злочином. Лужницький піднімає цю дражливу тему i хоча для читача/глядача очевидною $є$ позиція автора (він трактує вчинки «лицарів ночі», а отже й оунівців, як єдиний можливий опір та самозахист), все ж він не виступає, як остаточний суддя у цьому складному питанні. Устами героя проговорюється думка, що кожен все ж відповідатиме за свої вчинки перед Господом. Подібна дискусія звучить і у драмі «Іван Мазепа», де головний герой у своїй боротьбі за свободу прирівнюється до Месії. Він готовий на поразку і на смерть заради того, щоб майбутне покоління мало на що опертися у своїй національній історії. Мазепа веде діалог із Матір'ю-Ігуменею, котра ставить важливе питання - чи варта його жертва стількох життів, які він веде за собою, чи зможе він перед Богом відповісти за смерть цих людей. Це важливі глибокі питання, які ставить перед своїм глядачем драматург. Мазепу Лужницький вимальовує як месію-пророка, котрий, незважаючи на знання майбутнього (що йому відкриває Господь) все одно робить свій вибір на користь боротьби за гідність. Завдяки темам, що їх піднімає автор, та методам ведення диспуту на сцені можемо назвати зазначені історичні драми Лужницького інте- 
лектуальним театром, адже призначені вони для проговорення складних моральних питань.

Ще однією важливою історичною драмою Г. Лужницького є «Слово о полку Ігоревім». Поставлена 1937 року в театрі «Заграва» режисером В. Блавацьким.

Хоча конкретна релігійна тема тут звучить невиразно, у драмі помічаємо чіткі та впізнавані релігійні християнські сюжетні схеми. Перша - модель зради друга заради збагачення (Тевмаргос), друга — це модель блудного сина (Ігор — Ярослав Мудрий), третя — модель двох грішників - той, що кається, і той, що не жаліє за провини (Ігор Тевмаргос).

Перша модель втілюється завдяки розвиткові теми зради ближнього заради збагачення, влади. Ця тема у драмі «Слово о полку Ігоревім» гостро звучить через уведену Г. Лужницьким лінію купця Тевмаргоса, який зраджує свого друга, залишає серед ворогів заради збагачення. Власне, постать Пантелеймона Тевмаргоса $\epsilon$ різко негативною, фактично це єдиний абсолютно негативний персонаж у творі. Навіть половці Гза та Кончак із ворожого табору прочитуються радше як позитивні герої. Таким чином наголошується вага прихованої небезпеки з боку зрадливого друга, порівняно із видимою загрозою відвертого ворога. Конфлікт Тевмаргоса і його оточення звучить у п’єсі гостріше за конфлікт розрізнених, необ'єднаних князів. Тевмаргос виступає втіленням однієї з перешкод, що загрожують єдності на вищому рівні. Іншою загрозою на шляху до єдності є непослух. У драмі ця тема реалізується, власне, через вчинок Ігоря - його самовільний похід на половців. Лінія князя Ігоря - перебування у полоні, потім втеча - описується у другій дії та розвивається у четвертій. У цій лінії реалізується друга релігійна схема - модель притчі про блудного сина. Блудний син - це князь Ігор, який кається перед князем київським Святославом. Князь Святослав, як мудрий батько, пробачає синові його провину. У поемі «Слово о полку Ігоревім» немає виразного конфлікту, який би чітко втілювався через конфліктуючих героїв. Це прийнятне для жанру поеми, однак є неприпустимим для драматичного жанру. Театральна сцена все-таки вимагає зіткнення через конфліктуючі сторони. I якщо основна ідея твору — це єдність нації, то до драми-інсценізації потрібно було додати і засудити щось чи когось, хто б цю єдність порушував. Князь Ігор для цього не підходив, адже він покаявся перед князем київським і своїм народом. Тому Лужницький і створює підступного персо- нажа Пантелеймона Тевмаргоса, який, зрадивши друга, не відчуває каяття. Власне, Ігор та Тевмаргос, обидва зробивши лихий вчинок, протиставляються наче два грішники, один 3 яких кається, а другий — ні. I хоча між Тевмаргосом та Ігорем у п’єсі безпосереднього зіткнення немає, проте ці персонажі створюють у драмі дві протилежні поведінкові моделі: зрадника, що кається і фактично стає блудним сином, який покаявся і повертається до батька, та зрадника, який не відчуває власної провини. Так увиразнюється конфлікт, виявляючись у системі пріоритетів, цінностей героїв: що важливіше - своє, особисте, часом дріб'язкове і буденне, де в центрі світу «я» і рух навколо «мене», чи «я» є в русі для служіння іншим - це християнська концепція, де влада дається не для визискування задля особистої вигоди (як у випадку Тевмаргоса), а для служіння іншим (такими володарями із християнською свідомістю є, найперше, князь галицький Ярослав Осмомисл, княгиня Ярославна, київський князь Святослав, а наприкінці - i князь Ігор). Власне, трактування героя - виправдання його чи засудження не за самий вчинок, а крізь призму ставлення персонажа до своїх дій - кається у провині чи ні - відбувається за християнською ідеєю прощення. Християнська релігійність як принцип художнього мислення наскрізна у творчості Г. Лужницького - за цим принципом будуються конфлікти, розв'язки i не лише у релігійних драмах за жанром, а й у історичних творах, комедіях [13, 173].

Драма «Слово о полку Ігоревім» закінчується оптимістично, романтично-піднесено, присягою усіх князів руських єдиному князеві київському Святославу. Г. Лужницький досить ретельно в об'ємній ремарці (майже на півсторінки) вимальовує місце останньої дії. Дуже детально описує розташування місць, які поступово займатимуть князі. Із центральною фігурою київського князя ці місця мають утворити неперервну лінію на сцені, лінію, що її уявно протягував би глядач у залі, домальовуючи символічний, об'єднаний ланками ланцюжок. Зрештою відчуття піднесення, єдности, яке виникло у глядачів вистави театру «Заграва» 1937 року і про які читаємо у рецензіях $[14 ; 5]$, вочевидь були викликані завдяки вмілому режисерському поєднанню В. Блавацьким відповідної акторської гри, літературного тексту та мізансцен, що їх пропонує автор драматичного твору. Із конкретних вказівок Г. Лужницького про вигляд сцени і деяких мізансцен відчуваємо, що автор пише твір не для колись можливої постави, а для конкретної сцени, акторів і глядача. Драма- 
тург описує у п’єсі не місце дії взагалі, а місце дії, що відбуватиметься саме на тій сцені. За допомогою уявної сценографії автор драми створює для кожної знакової сцени відповідну атмосферу, наприклад - благословенного Богом галицького князя Ярослава Осмомисла під сонячним промінням, що спадає крізь вікно на задньому плані (у третій діï). Тут уже мала б бути не ілюстративна декорація, а така, що творить атмосферу і відображає внутрішній стан героя, можливі інші його характеристики. Відомо, що В. Блавацький у співпраці $з$ художником Леонідом Боровиком пішли ще далі, відтворивши у вікні княжого замку крилоську катедру, що іiі тоді розкопували ${ }^{2}$. Цей вдалий візуальний акцент зумів поєднати давні події iз тогочасними, стати символом «Правди і Справедливости» $[9,5]$.

Отже, бачимо, як Г. Лужницький у своїх iсторичних драмах піднімає питання української національної ідентичності, використовуючи християнські концепти, моделі, щоб увиразнити зазначену ідею, надати їй вагомості для реципієнта, котрий перебуває у полі християнської культури. Крім того, автор у творах ставить і проблеми національної боротьби з точки зору християнської моралі та етики. Драми Г. Лужницького загалом призначені не для читання, але для постав на сцені, звідки і мали публічно прозвучати згадані питання. Це підтверджує зрілість суспільства, принаймні його передової спільноти, готовність до обговорення морально-етичних проблем національної боротьби. Театральна форма, запропонована Г. Лужницьким апелює до модерних форм театру дискусії та може бути різновидом українського інтелектуального театру поч. XX ст.

\section{Джерела та література}

1. Атаманчук В. Образи історичних діячів у драмах Григора Лужницького. Сучасні проблеми мовознавства та літературознавства : збірник наукових пращь. ДВНЗ «Ужгород. нац. ун-т» ; відп. ред. І. В. Сабадош. Ужгород : Ужгородський нац. ун-т, 2018. Вип. 23. С. 21-23.

2. Вівчарик Н. Поетика драми Григора Лужницького «Голгота - Страсті, Смерть і Воскресіння Господа Нашого Iсуса Христа» [Текст]. Наукові записки ТДПУ ім. В. Гнатюка. Сер. Літературознавство. 2002. Вип. 1 (11). С. 139-147.

3. Возняк М. С. Історія української літератури : У 2 книгах: Навч. вид. Вид. 2-ге, перероб. Кн.1. Львів: Світ, 1992. $696 \mathrm{c}$.

4. Волицька I. «Монументальний театр» Володимира Блавацького. Записки Наукового товариства імені Т. Шев-

\footnotetext{
2 У 1930-х роках проводилися розкопки княжого Галича (давньоукраїнської столиці 31141 р.), який містився на території сучасного села Крилос (тепер Галицького району Івано-Франківської обл.), а кафедральний собор височів у самому центрі княжого "города".
}

ченка. Т. CCXXXVII. Праці театрознавчої комісії. Львів, 1999. C. 257.

5. Глядач «Слово о полку Ігоря» на сцені. Мета. Львів, 1937. 17 жовтня. Ч. 40. С. 8.

6. Дмитрів I. Національна ідея у творчості письменників-«логосівців». [Текст]. Літературологія. 2013. Вип. 1. C. 151-157.

7. Заїкін В. Християнство на Україні за часів кн. Ярополка I (969-979). OSBM. Жовква, 1928. Т. 3. С. 11.

8. Кошелінська М. Драми Григора Лужницького «Ой, зійшла зоря над Почаєвом» та «Голгота» у сценічній практиці галицького українського театру «Заграва» (19331938). Львів. 2005.

9. Кульчицький О. «Слово про полк Ігоря» на сцені. Премієра «Заграви» в Коломиї - історичне видовище на 4 відслони Г. Лужницького. Назустріч. Львів, 1937. 15 жовтня. Ч. 20. С. 5.

10. Лаврентій Р. Г. Лужницький «Голгота». Український Молодий театр «Заграва» (1936). Украӥнський театр XX cm.: Антологія вистав ; за заг.ред. М. Гринишиної. Київ: Фенікс, 2012. 964 с.

11. Лужницький Г. Літургійні елементи в історії українського театру. Український театр. Наукові праці, статті, рецензії: Збірник праць. Львів, 2004. Т. 1. Наукові праці. C. 116.

12. Рудницький Л. Драматургія Григора Лужницького. 3aписки наукового товариства імені Т. Шевченка. 1992. T.224. C. 185-209.

13. Хороб С. Українська драматургія: крізь виміри часу (Теоретичні та історико-літературні аспекти драми). Івано-Франківськ: Лілея-НВ, 1999. 200 с.

14. Чайківський Й. «Слово о полку Ігоря». Новий час. Львів, 1937. 11 жовтня. Ч. 225. С. 8; Кульчицький О. «Слово про полк Ігоря» на сцені. Назустріч. Львів, 1937. 15 жовтня. Ч. 20. C. 5.

\section{References}

1. Atamanchuk, V. (2018). Offenses of historical figures are in dramas by Hryhir Luzhnytskyi. Suchasni problemy movoznavstva ta literaturoznavstva : zb. nauk. Prats. Uzhhorod : Uzhhorodskyi nats. un-t. Vyp. 23. S. 21-23 [in Ukrainian].

2. Vivcharyk, N. (2002). Poetics drama by Hryhir Luzhnytskyi «Golgofa - Passions, Death and Resurration of Lord Our Jesus Christ» [Tekst]. Naukovi zapysky TDPU im. V. Hnatiuka. Ser. Literaturoznavstvo. Vyp. 1 (11). S. 139147 [in Ukrainian].

3. Vozniak, M. S. (1992). History of Ukrainian literature: U 2 knyhakh: Navch.vyd. Vyd. 2-he, pererob. Kn.1. Lviv: Svit. 696 [in Ukrainian].

4. Volytska, I. (1999). «Monumental theatre» of Volodymyr Blavatskyi. Zapysky Naukovoho tovarystva imeni T. Shevchenka. T. CCXXXVII. Pratsi teatroznavchoi komisii. Lviv. S. 257 [in Ukrainian].

5. Hliadach «A spectator is "Word oh to the regiment of Ihor" on the stage. (1937). Meta. Lviv. 17 zhovtnia. Ch. 40. S. 8 [in Ukrainian].

6. Dmytriv, I. (2013). A national idea is in work of writters«lohosivtsiv» [Tekst]. Literaturolohiia. Vyp. 1. S. 151-157 [in Ukrainian].

7. Zaikin,V.(1928). Christianity on Ukraine in the days of prince Yaropolk I (969-979). OSBM. Zhovkva. T. 3. S. 11 [in Ukrainian].

8. Koshelinska, M. (2005). Hryhir Luzhnytskyis dramas «Ouch, sunset climbed above

9. Pochaiev» and «Golgota» in a stage practice of the Galychina Ukrainian theatre Glow (1933-1938). Lviv [in Ukrainian]. Kulchytskyi, O. (1937). A «Word is about the Ihor regiment» 
on the stage. Premiiera «Zahravy» v Kolomyi - istorychne vydovyshche na 4 vidslony G. Luzhnytskoho. Nazustrich. Lviv. 15 zhovtnia. Ch. 20. S. 5 [in Ukrainian].

10. Lavrentii, R. (2012). H.Luzhnytskyi «Golgota». The Ukrainian Young theatre is «Glow» (1936). Ukrainskyi teatr XX st.: Antolohiia vystav. Kyiv: Fenix. 964 [in Ukrainian].

11. Luzhnytskyi, H. (2004). Liturgical elements are in history of the Ukrainian theatre. Ukrainskyi teatr. Naukovi pratsi, statti, retsenzii: Zbirnyk prats. Lviv, 2004. T. 1. Naukovi pratsi. S. 116 [in Ukrainian].
12. Rudnytskyi, L. (1992). Dramaturgy by Hryhir Luzhnytskyi. Zapysky naukovoho tovarystva imeni T. Shevchenka. T. 224. S. 185-209 [in Ukrainian].

13. Khorob, S. Ukrainian dramaturgy: through measuring of time (Theoretical and historical and literary aspects of drama). Ivano-Frankivsk, 1999. 200 [in Ukrainian].

14. Chaikivskyi, Y. (1937). "Word oh to the Ihor regiment». Novyi chas. Lviv. 11 zhovtnia. Ch. 225. - S. 8; Kulchytskyi, O. (1937). "Word oh to the Ihor regiment» na stseni. Nazustrich. Lviv. 15 zhovtnia. Ch. 20. S. 5 [in Ukrainian]. 